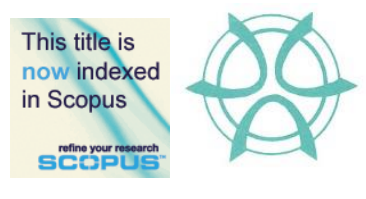

PLANNING MALAYSIA:

Journal of the Malaysian Institute of Planners

VOLUME 15 ISSUE 3 (2017), Page 51 - 62

\title{
URBAN SPATIAL PATTERN AND CARBON EMISSION INTERCONNECTIVITY IN A SUB-SAHARAN CITY, NIGERIA
}

\author{
Solomon Dyachia Zakka ${ }^{1}$, Ariva Sungandi Permana ${ }^{2}$, \& M. Rafee Majid ${ }^{3}$ \\ ${ }^{1,2,3}$ Department of Urban and Regional Planning, Faculty of Built Environment \\ UNIVERSITI TEKNOLOGI MALAYSIA \\ ${ }^{I}$ Department of Urban and Regional Planning, School of Environmental Studies \\ NUHU BAMALLI POLYTECHNIC, ZARIA-KADUNA STATE, NIGERIA
}

\begin{abstract}
This study analyses the spatial pattern of Kaduna City in Sub-Saharan region and its vicinity to ascertain its influence on urban interaction and implications towards carbon emission. It employed a questionnaire-based research for the collection of socio-economic, traffic and spatial data. Meanwhile, spatial data was derived in secondary form from relevant organizations. The study reveals a steady increase in the built-up areas which covered 17,121 hectares representing 53\% of the total area of the city. It also identified a mono-centric land use pattern for the city. The interconnection between the city centre and the residential areas has resulted in high traffic volume during the morning and evening peak hours on working days. The study also found that carbon emission at points along major routes in the city ranges between 1169 to1884 ppm. Considering the present performance of the city, the study suggests to adopt traditional red-ocean strategies, which are maximizing the carbon sequestration through optimizing urban ecology while minimizing the need for motorized transport using urban planning principles.
\end{abstract}

Keywords: Spatial pattern, emission, carbon sequestration, interconnectivity

Date Received: $11^{\text {th }}$ April 2017

Date of Acceptance: $25^{\text {th }}$ August 2017 
Solomon Dyachia Zakka, Ariva Sugandi Permana, \& M. Rafee Majid.

Urban Spatial Pattern and Carbon Emission Interconectivity in Sub-Saharan City, Nigeria

\section{INTRODUCTION}

The urban spatial pattern is a fundamental reflection of a city to accommodate urban growth and functionality over time (Linard, Tatem \& Gilbert, 2013). Gupta (2014), asserted that the urban land use is one of the important determinants of urban pattern and its activities. The most visible consequence of the connectivity and interplay between different urban land uses is reflected in the traffic generation that may encourage and boost socio-economic activities (Permana, Aziz \& Ho, 2015). In a developing country like Nigeria, the land use system is strongly affiliated with the road transport system, the emphasis has always been on how to enhance the mutual benefit in order to enhance the interaction of activities for the common good. However, in recent years the focus towards land use and transport has been tilted to embrace the component of the environment and climate change. On the climate change co-benefit approach from different sectors, Permana et al. (2015) developed the nexus of land use, transport, and environment as shown in Figure 1.

By considering the nexus model, it is estimated that $22 \%$ of greenhouse gas emission comes from the transport sector as confirmed by Freire (2013), while further breakdown shows that motorized transport contributes to emission release for approximately $90 \%$ of $\mathrm{CO}_{2}$ emission (UNEP, 2012). In some developed countries, researches have revealed that changing land use pattern may likely be an essential element in reducing greenhouse gas emission from the transport sector. For example, a study of anticipated impact of land use on $\mathrm{CO}_{2}$ emission shows that a $60 \%$ shift in new residential growth to compact patterns in the USA may help reduce carbon emission by $7 \%$ to $10 \%$ (Ewing et al., 2008). Similarly, the Global Opportunity Network (2016) pointed out that the transition of cities can impact positively on reducing air pollution and carbon emission. Furthermore, emphasis on emerging economies of third world countries shows that major portions of urban land use patterns can still be easily influenced towards the reduction of future automobile transport dependence and its ills.

In many developed countries of Western Europe and Northern America, as well as rapidly developing countries of South-East Asia, an integrated approach in harmonizing land use and transport towards sustainability and carbon emission reduction has already been entrenched through the green growth concept (Badoe \& Miller, 2000; Frank, 2000; Shaw \& Xin, 2003). However, the developing countries of sub-Saharan Africa are still bedevilled with the challenges of weak land use planning and development control as well as uncoordinated transport system that are capable of generating high amount of air pollution at the local level and leaving large carbon footprint on the global front. The current land use pattern of many urban areas in sub-Saharan Africa can be associated with the land use planning system inherited from their colonial masters. For example, Aribigbola (2008) asserted that the Nigerian planning 
system was cruelly outdated, and was anchored on the 1946 Act which was a product of 1932 town and country planning act in the United Kingdom.

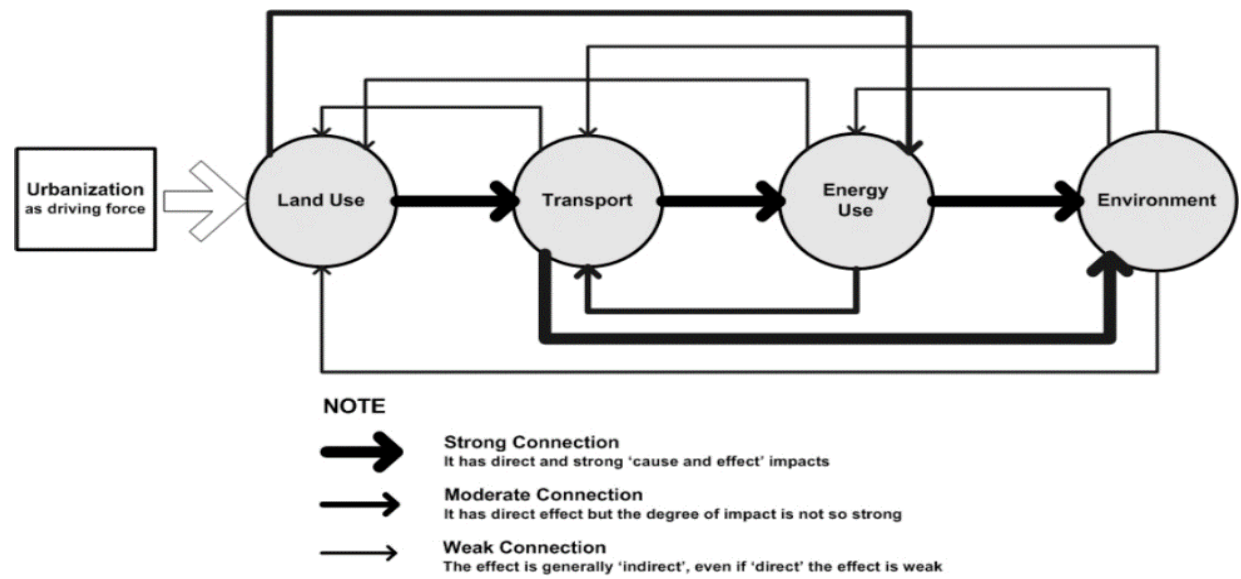

Figure 1 Land use, Transport and Environment Nexus Source: Permana et al.,2015

One major challenge facing many African cities is the mono-centric land use pattern which is characterized by the over concentration of activities at a single central business district. This current trend of African urban land use pattern and growth have daunted urban development. Furthermore, it increases dependence on fossil fuel automobile, thus increases emission. It, therefore, has attracted global effort in the ongoing campaign on climate change as identified by Angel et al. (2005) and Stocker (2014).

The aim of this study is to analyse the spatial pattern of Kaduna city and its vicinity to ascertain its influence on the urban mobility pattern and its implications towards carbon emission. In order to achieve the aim, the following objectives were set out, which are to identify the spatial pattern of the city with regard to its land use arrangement, to assess the level of commuters interaction and to ascertain the volume and direction of traffic flow resulting from commuters interaction in the city, to ascertain the quantity of $\mathrm{CO}_{2}$ emission stem from the traffic flow, to establish the relationship between the traffic flow and $\mathrm{CO}_{2}$ emission, and finally to come up with functional recommendation based on the findings of the study.

\section{RESEARCH METHODOLOGY}

Kaduna City, which is the study area, was founded in 1907 by the British colonist and was made the capital of Northern Nigeria region in 1917. Kaduna urban area with a population of $1,139,578$, based on 2006 census figure (FGN, 2007) was 
Solomon Dyachia Zakka, Ariva Sugandi Permana, \& M. Rafee Majid.

Urban Spatial Pattern and Carbon Emission Interconectivity in Sub-Saharan City, Nigeria

ranked third in Northern Nigeria with respect to population size after Kano and Abuja.

Both primary and secondary data were collected to support the analysis for this study. Kaduna urban area Landsat imageries were retrieved to show land cover/land use trend from 1982 to 2015. Emphasis was given on the trend of urban growth through the expansion of the built up area. A digitized map was used to depict the land use pattern of the city and a breakdown of land use categories for 2015. Parah Konsult, a consultancy firm, has supplied the digital data in ArcGIS format, and analysis was carried out using ArcGIS 10.2 software. In order to generate traffic data to understand the weekly and monthly trends as well as peak hours of traffic flow, a non-intrusive technique based on manual counting of traffic using tally sheet by trained research assistance was used. Four selected points along the major routes leading to the city centre were used for the count. Similarly, $\mathrm{CO}_{2}$ emission data generated along major routes leading to the city centre were obtained from Kaduna State Environmental Protection Agency (KEPA).

In order to ascertain the level of commuters interaction between various residential neighbourhoods and the central area, a questionnaire survey was conducted on a sample of $n=600$ from the general population of $N=>1,000,000$. Commuters' daily trips were considered across the city, taking into cognizance the population as a parameter for the number of trips generated by each residential neighbourhoods. Analysis on socio-economic data e.g. respondents' attributes and perceptions were then carried out. Finally, a nonlinear regression analysis was carried out to establish the relationship between carbon emission and the traffic volume in the city.

The carbon sequestrations estimation was based on the interpretation of satellite imagery of the vegetation in the City supported by aerial photographs and samples of the ground survey.

\section{DATA ANALYSIS AND FINDINGS}

\section{The Trend of Land Use cover and Land Use Pattern}

Table 2 shows that the built up area of 8,440 hectares in 1980 has gradually increased to 10,242 hectares in 2000, indicating an average increase of $1-2 \%$ in every ten-year period. The built-up area growth rate during the period of 20002015 has been doubled compared to the period of 1980-2000.

The increase of built-up area over the years as shown in Table 2 is certainly at the expense of the decreasing natural area, as the urban area of Kaduna city is practically constant. The changing landscape of Kaduna City due to urban development occurs mostly on farmland and vegetation. The decrease of farmland accounted for about $2.0 \%$ in five year period, while the vegetation 
reduced by $1-2 \%$ in the same period. The conversion of bare land to a built-up area, on the other hand, accounted for only $0.8 \%$.

Table 2 Land use development in Kaduna City (1980-2015)

\begin{tabular}{|c|c|c|c|c|c|c|c|c|c|}
\hline & & 1980 & 1985 & 1990 & 1995 & 2000 & 2005 & 2010 & 2015 \\
\hline & $\begin{array}{l}\text { Land Use } \\
\text { Categories }\end{array}$ & $\begin{array}{l}\text { Area in } \\
\text { Hectares } \\
(\%)\end{array}$ & $\begin{array}{l}\text { Area in } \\
\text { Hectares } \\
(\%)\end{array}$ & $\begin{array}{l}\text { Area in } \\
\text { Hectares } \\
(\%)\end{array}$ & $\begin{array}{l}\text { Area in } \\
\text { Hectares } \\
(\%)\end{array}$ & $\begin{array}{l}\text { Area in } \\
\text { Hectares } \\
(\%)\end{array}$ & $\begin{array}{l}\text { Area in } \\
\text { Hectares } \\
(\%)\end{array}$ & $\begin{array}{l}\text { Area in } \\
\text { Hectares } \\
(\%)\end{array}$ & $\begin{array}{l}\text { Area in } \\
\text { Hectares } \\
(\%)\end{array}$ \\
\hline 1 & Built up & $\begin{array}{l}8,440 \\
(18.8) \\
\end{array}$ & $\begin{array}{l}8,775 \\
(19.6) \\
\end{array}$ & $\begin{array}{l}9,110 \\
(20.3)\end{array}$ & $\begin{array}{l}9,676 \\
(21.5) \\
\end{array}$ & $\begin{array}{l}10,242 \\
(22.7)\end{array}$ & $\begin{array}{l}11,959 \\
(26.5)\end{array}$ & $\begin{array}{l}13,677 \\
(30.1)\end{array}$ & $\begin{array}{l}15,394 \\
(33.8)\end{array}$ \\
\hline 2 & Farm land & $\begin{array}{l}23,175 \\
(51.7)\end{array}$ & $\begin{array}{l}22,940 \\
(51.2)\end{array}$ & $\begin{array}{l}22,705 \\
(50.7)\end{array}$ & $\begin{array}{l}21,693 \\
(48.30\end{array}$ & $\begin{array}{l}20680 \\
(45.9)\end{array}$ & $\begin{array}{l}19,804 \\
(43.8)\end{array}$ & $\begin{array}{l}18,928 \\
(41.7)\end{array}$ & $\begin{array}{l}18,052 \\
(39.6)\end{array}$ \\
\hline 3 & Vegetation & $\begin{array}{l}10,020 \\
(22.4)\end{array}$ & $\begin{array}{l}9,970 \\
(22.2) \\
\end{array}$ & $\begin{array}{l}9,920 \\
(22.1) \\
\end{array}$ & $\begin{array}{l}9,749 \\
(21.7) \\
\end{array}$ & $\begin{array}{l}9,578 \\
(21.3)\end{array}$ & $\begin{array}{l}9,257 \\
(20.5) \\
\end{array}$ & $\begin{array}{l}8,937 \\
(19.7)\end{array}$ & $\begin{array}{l}8,616 \\
(18.9)\end{array}$ \\
\hline 4 & Bare land & $\begin{array}{l}2,150 \\
(4.8)\end{array}$ & $\begin{array}{c}2,100 \\
(4.7)\end{array}$ & $\begin{array}{l}2,050 \\
(4.6)\end{array}$ & $\begin{array}{c}2,770 \\
(6.2)\end{array}$ & $\begin{array}{c}3,489 \\
(7.7) \\
\end{array}$ & $\begin{array}{c}3,178 \\
(7.0)\end{array}$ & $\begin{array}{l}2,866 \\
(6.3)\end{array}$ & $\begin{array}{l}2555 \\
(5.6) \\
\end{array}$ \\
\hline 5 & $\begin{array}{l}\text { Water } \\
\text { Body }\end{array}$ & $\begin{array}{l}1,040 \\
(2.3)\end{array}$ & $\begin{array}{l}1040 \\
(2.3)\end{array}$ & $\begin{array}{l}1040 \\
(2.3)\end{array}$ & $\begin{array}{l}1040 \\
(2.3) \\
\end{array}$ & $\begin{array}{l}1,040 \\
(2.3)\end{array}$ & $\begin{array}{l}1006 \\
(2.2)\end{array}$ & $\begin{array}{l}972 \\
(2.1)\end{array}$ & $\begin{array}{l}937 \\
(2.1)\end{array}$ \\
\hline & Total & 44,825 & 44,825 & 44,825 & 44.927 & 45,029 & 45,204 & 45,378 & 45,553 \\
\hline
\end{tabular}

Source: Parah Konsult, 2015

\section{The Mono-Centric Land Use Pattern in Kaduna.}

Data analysed on an intra-city commuter trip for twenty-one residential neighbourhoods spread across the city is shown in Table 3. It reveals that out of 600 daily trips generated, $57.5 \%$ of the travels were made towards Central Business District (CBD) or city centre. This fact reflects that CBD becomes the single destination by the majority of citizens, and it also shows that strong influence of British planning mind-set in city planning system of Kaduna that has brought down for decades since the colonialism era. For many reasons, a monocentric city in most developing countries has generated environmental consequences from transportation sources (Permana et al.,2015).

Table 3 Trip Generated by Commuters in Kaduna Urban Area

\begin{tabular}{|c|c|c|c|c|c|c|}
\hline No & $\begin{array}{l}\text { Name of } \\
\text { neighbourhood }\end{array}$ & $\begin{array}{c}\text { Distance of } \\
\text { neighbourhood } \\
\text { from city } \\
\text { centre }(\mathrm{km})\end{array}$ & $\begin{array}{l}\text { Frequency } \\
\text { of trip } \\
\text { generated }\end{array}$ & $\begin{array}{l}\text { Commuter trip } \\
\text { within the } \\
\text { same } \\
\text { neighbourhood }\end{array}$ & $\begin{array}{l}\text { Commuter trip } \\
\text { outside the } \\
\text { neighbourhood }\end{array}$ & $\begin{array}{l}\text { Commuter } \\
\text { trip to the } \\
\text { central } \\
\text { business } \\
\text { district }\end{array}$ \\
\hline 1 & Sabon Tasha & 14.07 & 50 & $8(16 \%)$ & $16(32 \%)$ & $26(52 \%)$ \\
\hline 2 & Maraban Rido & 21 & 20 & $0(00 \%)$ & $4(20 \%)$ & $16(80 \%)$ \\
\hline 3 & Narayi & 5.97 & 35 & $4(11.43 \%)$ & $9(25.71 \%)$ & $22(62.86 \%)$ \\
\hline 4 & Barnawa & 5.23 & 42 & $10(23.81 \%)$ & $4(9.52 \%)$ & $28(66.67 \%)$ \\
\hline 5 & Kakuri & 8.1 & 30 & $4(13.33 \%)$ & $7(23.34 \%)$ & $19(66.33 \%)$ \\
\hline 6 & Gonin Gora & 10.84 & 20 & $2(10 \%)$ & $7(35 \%)$ & $11(55 \%)$ \\
\hline 7 & Kawo & 7.4 & 70 & $11(15.72 \%)$ & $18(25.72)$ & $41(58.57 \%)$ \\
\hline 8 & $\begin{array}{l}\text { Angwar } \\
\text { Malali/Rimi }\end{array}$ & 3.86 & 40 & $5(12.5 \%)$ & $14(35 \%)$ & $21(52.5)$ \\
\hline 9 & $\begin{array}{l}\text { Angwar } \\
\text { Television }\end{array}$ & 8.58 & 15 & $2(13 \%)$ & $6(40 \%)$ & $7(47 \%)$ \\
\hline
\end{tabular}


Solomon Dyachia Zakka, Ariva Sugandi Permana, \& M. Rafee Majid.

Urban Spatial Pattern and Carbon Emission Interconectivity in Sub-Saharan City, Nigeria

\begin{tabular}{llccccc}
10 & Mando & 10.40 & 25 & $2(8 \%)$ & $6(24 \%)$ & $17(68 \%)$ \\
11 & Nasarawa & 6.71 & 20 & $7(35 \%)$ & $4(20 \%)$ & $9(45 \%)$ \\
12 & Angwar shanu & 3.1 & 10 & $2(20 \%)$ & $3(30 \%)$ & $5(50 \%)$ \\
13 & Angwar & 4.97 & 15 & $1(6.67 \%)$ & $6(40 \%)$ & $8(53.33 \%)$ \\
& Mauzu & & & & \\
14 & Angwar Dosa & 5.55 & 35 & $8(22.86 \%)$ & $12(34.29)$ & $15(42.85 \%)$ \\
15 & Angwar Romi & 9.90 & 30 & $5(16.67 \%)$ & $10(33.33 \%)$ & $15(50 \%)$ \\
16 & Kabala costain & 2.70 & 10 & $1(10 \%)$ & $3(30 \%)$ & $6(60 \%)$ \\
17 & Rigachikun & 14.50 & 14 & $1(7.14 \%)$ & $3(21.43 \%)$ & $10(71.43 \%)$ \\
18 & Kurmin & 3.93 & 13 & $00(00 \%)$ & $4(30.77 \%)$ & $9(69.23 \%)$ \\
& Mashi/Badiko & & & & & $23(46 \%)$ \\
19 & Angwar & 5.67 & 50 & $1(2 \%)$ & & $26(52 \%)$ \\
& Rigasha/Sanusi & & & & & \\
20 & Tudun wada & 2.45 & 36 & $5(13.89 \%)$ & $21(58.33 \%)$ & $10(27.78 \%)$ \\
21 & Central area & - & 20 & $16(80 \%)$ & $4(20 \%)$ & - \\
\hline & Total/Average & & 600 & $12.3 \%$ & $30.2 \%$ & $57.5 \%$ \\
\hline
\end{tabular}

Source: Field Survey 2015

The distance of all neighbourhoods from the city centre ranges between $2.45 \mathrm{~km}$ to $11.60 \mathrm{~km}$, while the average willingness to walk for the citizens, based on the questionnaire survey, was 1,100 meters. This reflects that beyond $1.1 \mathrm{~km}$ people tend to accomplish their travel by using motorized modes of travel, either private or public transport. A correlation test between distance and trip generation to the city centre give an R-Square of 0.076 . This result reflects a non-significant relationship between the two variables. It also means that the high trips generated to the CBD may be attributed to economic gain derived from the jobs and economic activities in the city hubs. Mobility is not limited by distance as in this case.

\section{Land Use Pattern Influence on Traffic Flow and Implication for $\mathrm{Co}_{2}$ Emission}

The mobility pattern in the city shows the very high intra-city interaction between the peripheral medium and high residential land use and the agglomerated urban core. The city centre is a predator of commuter trips produced by the residential neighbourhoods. The flow of traffics towards the same direction during the working days generates high traffic volume along major routes leading to the city centre. Figure 4, shows the daily pattern of traffic volume along designated major routes. The traffic pattern at four selected points shows similarity on the cycle which is the morning peak hour between 7:00-8:00 am, while evening peak hour between 17:00-18:00hrs. The peak hours reflect the peak traffic volume where most citizens are on the road towards their destinations, particularly for working purpose or heading home. During peak hours, the carbon emissions are expected to be the highest. The traffic volume was counted in Kawo, Kasuwa (Market), Station at Roundabout and Sabon Tasha. 
PLANNING MALAYSIA

Journal of the Malaysia Institute of Planners (2017)

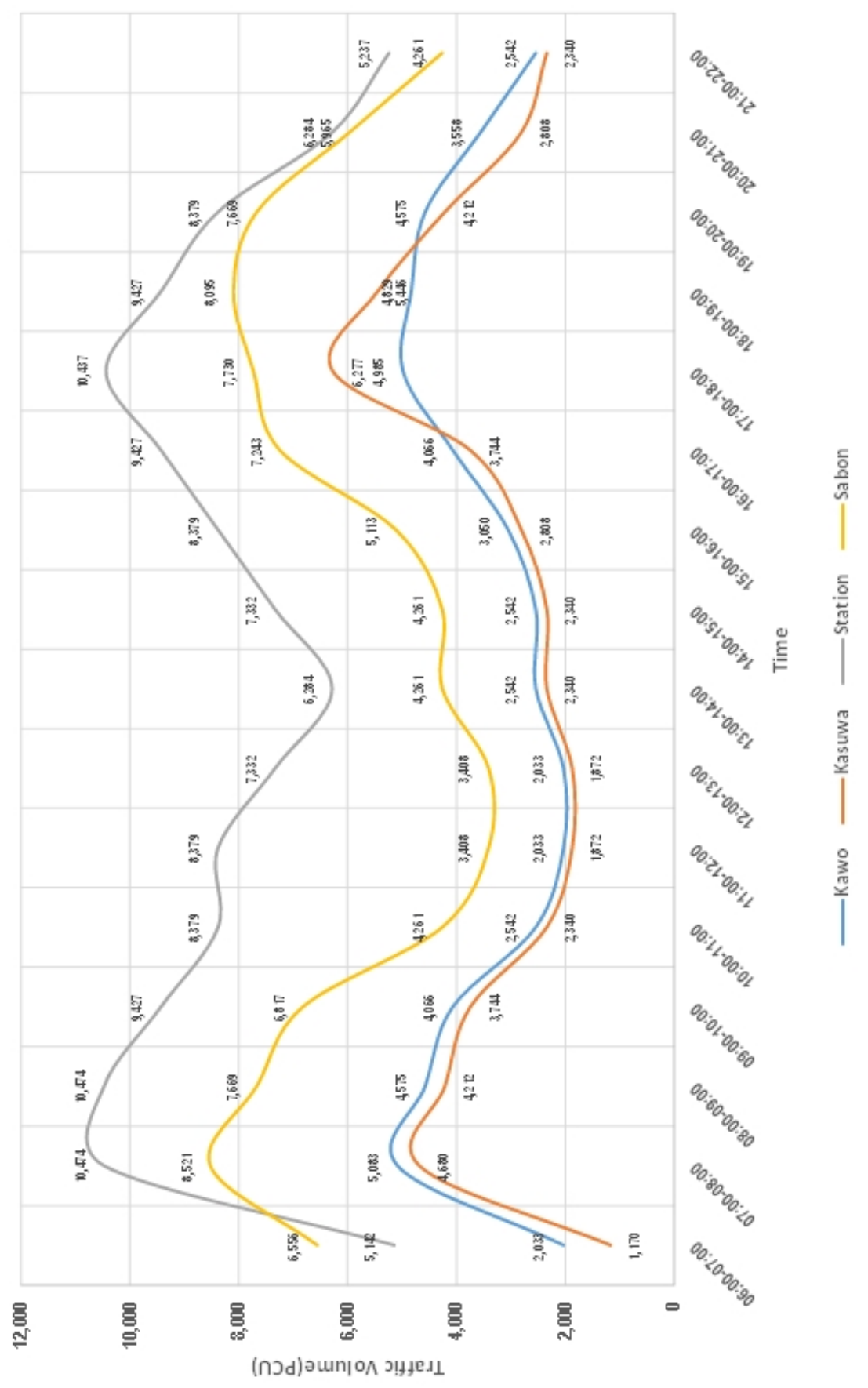

Figure 4 Daily Traffic Flow Pattern in 4 selected Points 
Solomon Dyachia Zakka, Ariva Sugandi Permana, \& M. Rafee Majid.

Urban Spatial Pattern and Carbon Emission Interconectivity in Sub-Saharan City, Nigeria

OECD (2007) argue that high traffic volume in mono-centric city leads to excessive congestion, therefore resulting to queuing, stretching of travel time, stress and increase emission due to prolonged combustion. Traffic congestion in many cities in Nigeria was attributed to the causes of poor road network, poor urban spatial arrangement and poor driving habits as identified by Bashiru (2008), Remi, Adegoke and Oyerinde (2009), Aderamo and Atomode (2012), and Ukpata $\&$ Etika (2012). In this case, the land use pattern, which influences the direction of traffic flow, has proven as a factor contributing to urban traffic congestion in Kaduna.

One of the most significant causes of urban traffic congestion is the extension of travel time, which is irritating for many urban people. This aspect can also be translated to more fuel consumption; and fuel consumption is directly related to $\mathrm{CO}_{2}$ emission. A non-linear regression was carried out on the two major variables, in which the volume of traffic representing the independence variable was used against the dependable variable represented by the values of carbon emission resulting from the hourly monitoring. The correlation between traffic volume and carbon emission in Kaduna can be described as a function of Carbon Emission [in ppm] $=125.52$ [Traffic Volume, in PCU] $]^{0.2848}$ with R-square is 0.5338 (Figure 5). Hence, it is deduced that there was a significant positive relationship between traffic volume and carbon emission. The strength of association between the variables shows a positive and strong relationship as $\mathrm{R}$ square values skewed towards one. The absence of industrial activities along the major roads means carbon emission from industrial source was negligible. Thus, it can be safely concluded that the source of carbon emission was solely the transportation sector. This condition further buttressed the relationship. Above all, the scenario from this study shows that an increase in traffic volume along major routes in the city will likely lead to increasing level of $\mathrm{CO}_{2}$ emission over time. The air concentration of $\mathrm{CO}_{2}$ gas in selected locations along traffic routes in the city ranges between $1,457 \mathrm{ppm}$ to $1,884 \mathrm{ppm}$ as plotted in Figure 5.

\section{Carbon Sequestration Estimate in Kaduna City.}

Using the method provided by Smith et al., (2006), the study estimated the carbon sequestration of the urban forest in Kaduna and surrounding areas. According to Keay, Onochie and Stanfield (1964), there were about 900 different kind of trees in Nigeria and sub-Saharan countries in general. Understory trees, which have a height less than 25-foot tall are excluded in the calculation of carbon sequestration capacity. 
PLANNING MALAYSIA

Journal of the Malaysia Institute of Planners (2017)

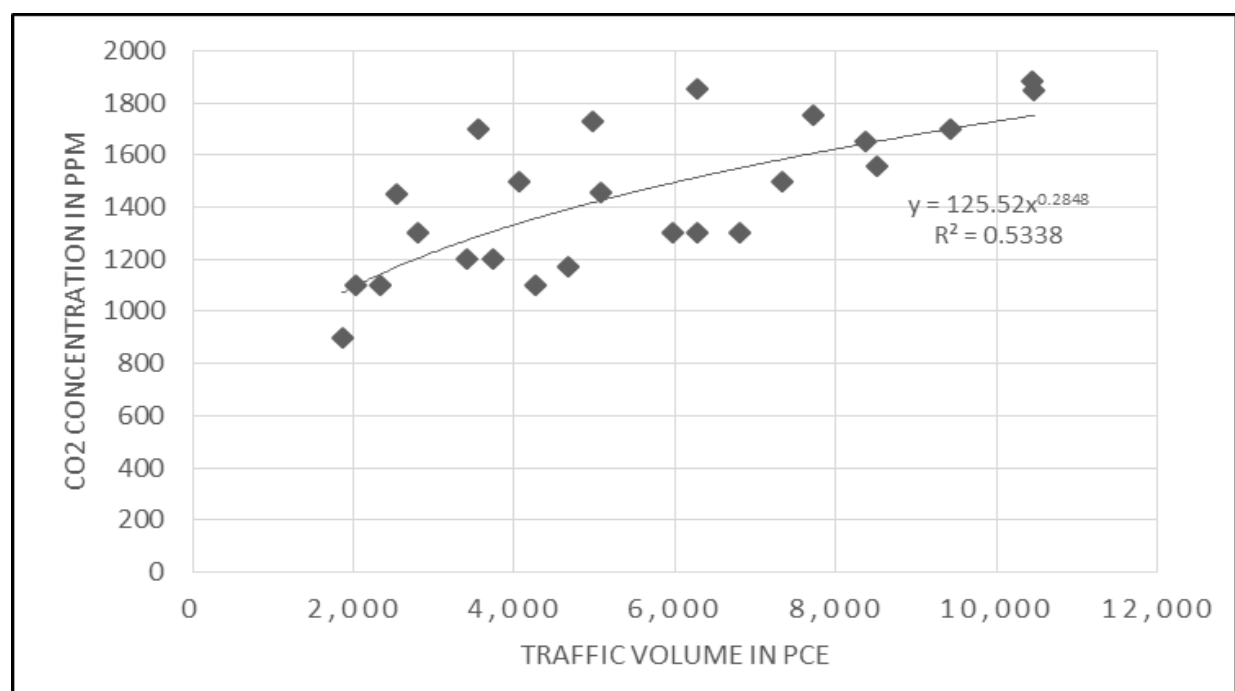

Figure 5 The relationship between Carbon Emission and Traffic Volume in Kaduna

Based on the findings from Keay, Onochie and Stanfield (1964), and ground checking with the Department of Forest Research of Nigeria as well as supported by recent aerial photographs, and Google Earth and Google Maps imageries, it is estimated that the urban forest in Kaduna and the surroundings area has the sequestration capacity as shown in Table 5.

Table 5 Carbon Sequestration Capacity of Kaduna Urban Forest

\begin{tabular}{|c|c|c|c|c|c|c|c|}
\hline $\begin{array}{c}\text { Carbon } \\
\text { sequestratio } \\
\mathrm{n} \text { in } \\
\text { Kaduna } \\
\text { City }\end{array}$ & $\begin{array}{c}\text { Mean vol } \\
\text { (m3/ha) }\end{array}$ & $\begin{array}{l}\text { Live tree } \\
\text { (ton } \mathrm{c} / \mathrm{ha} \text { ) }\end{array}$ & $\begin{array}{c}\text { Standing } \\
\text { dead tree } \\
\text { (tc/ha) }\end{array}$ & $\begin{array}{l}\text { Understo } \\
\text { ry (tc/ha) }\end{array}$ & $\begin{array}{l}\text { Down } \\
\text { dead } \\
\text { wood } \\
\text { (tc/ha) }\end{array}$ & $\begin{array}{l}\text { Forest } \\
\text { floor } \\
\text { (tc/ha) }\end{array}$ & $\begin{array}{c}\text { Organic } \\
\text { soil (tc/ha) }\end{array}$ \\
\hline $\begin{array}{c}\text { Per Unit } \\
\text { (m3/ha or } \\
\text { tC/ha) }\end{array}$ & 155.3 & 73.8 & 2.4 & 2.9 & 6.1 & 8.1 & 41.9 \\
\hline $\begin{array}{c}\text { Total } \\
\text { Sequestrati } \\
\text { on Capacity } \\
\text { (m3 or ton } \\
\text { of C) }\end{array}$ & $1,319,625.0$ & $627,300.0$ & $4,080.0$ & $24,650.0$ & $7,777.5$ & $68,850.0$ & $106,845.0$ \\
\hline
\end{tabular}

While the total carbon sequestration capacity of urban forest of Kaduna City is around 839,000 ton of carbon and will increase about $1.0 \%$ or about 8,390 ton carbon annually, the estimate annual total carbon emission produced in Kaduna City is about 3,170 ton. Thus, annual carbon emission can be absorbed 
Solomon Dyachia Zakka, Ariva Sugandi Permana, \& M. Rafee Majid.

Urban Spatial Pattern and Carbon Emission Interconectivity in Sub-Saharan City, Nigeria

by natural sequestration. However, the crucial issue on carbon emission in Kaduna is not on the sequestration capacity of the urban forest in Kaduna and surrounding area, rather the above acceptable level of $\mathrm{CO}_{2}$ emission. This means that, with respect to $\mathrm{CO}_{2}$ emission, Kaduna city is an unhealthy city, as average $\mathrm{CO}_{2}$ emission in Kaduna is above the acceptable safe standard air quality limit of $350 \mathrm{ppm}$.

\section{CONCLUSION}

The land use pattern of the city is a function of a weak land use planning system over the years. The concentric spatial expansion has resulted to spatial mismatched between land uses in the city. The segregation between the residential land use and the location of job opportunities has created an upsurge in the mobility and also influences the mobility pattern of the city. Based on this study, a new approach to urban planning that will help to restructure the urban land use pattern in order to reduce high dependence on automobile within the urban centre should be the focus. Considering the benefit of compact development over fragmentation, in terms of enhancing a vibrant, healthy, friendly, liveable and walkable urban centre (Brandes et al., 2010) urban planning should be used as a functional tool that will help mitigate the causes of climate change and reduces it impacts and vulnerability overtime. Furthermore, neutralizing the predatory strong ability of the urban core by creating growth poles at different neighbourhoods at a close distance across the city will help to reduce high dependence on the automobile, thus reducing traffic congestion and $\mathrm{CO}_{2}$ emission from traffic. Finally, the integration and adoption of functional mass transit programme to link area of high density will also help reduce traffic congestion resulting from commuter's high use of private cars.

The above though may not be workable for the time being, considering the present performance of Kaduna city. However, some of them are not impossible to implement as long as there exists political will of the authority. 


\section{REFERENCES}

Aderamo, A. J., \& Atomode, T. I. (2012). Traffic congestion at road intersection in Ilorin, Nigeria. Australian Journal of Basics and Applied Sciences, 5(9), 1439-1448.

Angel, S., Chabaeva, A., Gitlin, L., Kraley, A., Parent, J., \& Micah, P. (2005). The dynamics of global urban expansion. Washington DC: World Bank.

Aribigbola, A. (2008). Imroving urban land use planning and management in Nigeria: the case of Akure. Theoretical and Empirical Researches in Urban Management, 9(3), 1-14.

Badoe, D. A., \& Miller, E. J. (2000). Transportation-land-use interaction: empirical findings in North America, and their implications for modeling. Transportation Research Part D: Transport and Environment, 5(4), 235-263.

Bashiru, A. R. (2008). Analysis of intra-urban traffic problems in Nigeria: a study of Lagos metropolis. Indonesian Journal of Geography, 40(1). Doi: 10.22146/ijg.2246.

Brandes, U., MacCleery, R., Peterson, J., \& Johnston, M. (2010). Land use and driving: the role compact development can play in reducing greenhouse gas emissions. Washington, DC: Urban Land Institute.

Ewing, Bartholomew, K., Winkelman, S., Walters, J., Chen, D., McCann, B., \& Goldberg, D. (2008). Growing cooler: the evidence on urban development and climate change. Washington, DC: Urban Land Institute.

Federal Government of Nigeria [FGN] (2007). Federal Government of Nigeria 2006 population census. Official gazatte (FGP 71/52007/2,500(OL24). Lagos: Government Press.

Frank, L. D. (2000). Land use and transportation interaction implications on public health and quality of life. Journal of Planning Education and Research, 20(1), 6-22.

Freire, M. (2013). Urbanization and green growth in Africa: green growth series report no. $1 . \quad$ Retrieved from http://www.greengrowthknowledge.org/resource/urbanization-and-greengrowth-africa

Gupta, R. (2014). The pattern of urban land-use changes: A case study of the Indian cities. Environment and Urbanization Asia, 5(1), 83-104.

Keay, R., Onochie, C., \& Stanfield, D. (1964). Nigerian trees. Ibadan, Nigeria: Federal Department of Forest Research.

Linard, C., Tatem, A. J., \& Gilbert, M. (2013). Modelling spatial patterns of urban growth in Africa. Applied Geography, 44, 23-32.

OECD (2007). Managing urban traffic congestion. Paris: OECD.

Parah Konsult (2015). Land use development in Kaduna urban area (1980-2015). Zaria, Nigeria.

Permana, A. S., Abdul Aziz, N., \& Ho, C. S. (2015). Land use, urban mobility and environment nexus: evidence from a developing city. Johor Bahru: UTM Press.

Permana, A. S., Perera, R., Abdul Aziz, N. A., \& Ho, C. S. (2015). Corroborating the land use change as primary determinant of air quality degradation in a concentric city. International Journal of Built Environment and Sustainability. Doi: http://dx.doi.org/10.11113/ijbes.v2.n2.60 
Solomon Dyachia Zakka, Ariva Sugandi Permana, \& M. Rafee Majid.

Urban Spatial Pattern and Carbon Emission Interconectivity in Sub-Saharan City, Nigeria

Remi, A., Adegoke, A.-A. I., \& Oyerinde, A. (2009). A study of the causes, effects and ameliorative measures of road traffic congestion in Lagos Metropolis. European Journal of Social Sciences, 11(1), 119-128.

Global Opportunity Network (2016). Global Opportunity Report 2016. Havik, Oslo.

Shaw, S.-L., \& Xin, X. (2003). Integrated land use and transportation interaction: a temporal GIS exploratory data analysis approach. Journal of Transport Geography, 11(2), 103-115.

Smith, J. E., Heath, L. S., Skog, K. E., \& Birdsey, R. A. (2006). Methods for calculating forest ecosystem and harvested carbon with standard estimates for forest types of the United States. Retrieved from https://www.treesearch.fs.fed.us/pubs/22954

Stocker, T. F. (2014). Climate change 2013: the physical science basis. Cambridge: Cambridge University Press.

Ukpata, J. O., \& Etika, A. A. (2012). Traffic congestion in major cities of Nigeria. International Journal of Engineering and Technology, 2(8), 1433-1438.

UNEP. (2012). The Emission Gap Report 2012. Nairobi: United Nations Environment Programme (UNEP). 